\title{
What Function Is Served By MHC Upregulation in Neural Cells?
}

\author{
L.A. Lampson, A. Grabowska, M.P. Sethna, P. Wen, and J.P. Whelan \\ Center for Neurologic Diseases, Department of Neurology, Brigham and Women's Hospital and Harvard \\ Medical School, Boston MA 02115, USA
}

The possibility of immune rejection, and the role of the major histocompatibility complex (MHC) proteins, in neural transplantation is increasingly appreciated. Although MHC proteins are not detected in normal neural cells in situ, greater expression has been reported following transplantation, trauma, or growth in culture. The function served by this upregulation is not known; a non-immunological role in development or tissue repair has been proposed. We asked whether similar upregulation occurs during normal development or regeneration, or after exposure to immunoactive cytokines.

Immunostaining was used to reveal class I and II MHC antigens in neural tissues in situ, as listed in Table I. Among these tissues, strong MHC expression by microglia, endothelial cells, ependymal cells, connective tissue cells, and inflammatory cells was seen. Yet, MHC expression was not detected in neurons, astrocytes, or oligodendrocytes in any case. Nor were growth or cell contacts of neuroblastoma cell lines dependent upon MHC expression /1/.

Taken together, our findings do not reveal a non-immunological role for MHC upregulation in neural development, regeneration or homeostasis. Thus, it may be possible to prevent the MHC upregulation that has been reported in other contexts, without compromising normal neural function.

TABLE I

\section{CNS TISSUES IN WHICH NEITHER MHC CLASS I NOR CLASS II WAS DETECTED IN NEURONS OR GLIA}

\begin{tabular}{|c|c|}
\hline KIND OF TISSUE & SPECIFIC TISSUES EXAMINED* \\
\hline Normal adult CNS. & Human brain; spinal cord. Rat brain. Mouse brain. \\
\hline Barrier-free CNS. & Mouse, area postrema; stab wound. Rat stab wound. \\
\hline IFN-g-treated CNS. & Mouse brain. Rat brain. \\
\hline Regenerating/developing. & $\begin{array}{l}\text { Mouse, olfactory epithelium; developing embryo. Rat, } \\
\text { developing embryo. }\end{array}$ \\
\hline Pathological. & $\begin{array}{l}\text { Human brain, demyelinating disease. Human spinal cord, ALS. } \\
\text { Human brain, tumor-associated. Rat brain, tumor-associated. }\end{array}$ \\
\hline
\end{tabular}

*For original reports, see refs. 2-8, and Grabowska and Lampson, this volume (11.P4). 


\section{REFERENCES}

1. Lampson LA. MHC regulation in neural cells: Distribution of peripheral and internal b2-microglobulin and class I molecules in human neuroblastoma cell lines. J Immunol 1990; 144: 512-520.

2. Lampson LA, Hickey WF. Monoclonal antibody analysis of MHC expression in human brain biopsies: Tissue ranging from "histologically normal" to that showing different levels of glial tumor involvement. J Immunol 1986; 136: 4054-4062.

3. Lampson LA, Kushner PD, Sobel RA. Major histocompatibility antigen expression in the affected tissues in amyotrophic lateral sclerosis. Ann Neurol 1990; 28: 365-372.

4. Lampson LA, Wen P, Roman VA, Morris JH, Sarid JA. Disseminating tumor cells and their interactions with leukocytes visualized in the brain. Cancer Res 1992; 52: 1008-1025.
5. Sethna MP, Lampson LA. Immune modulation within the brain: Recruitment of inflammatory cells and increased major histocompatibility antigen expression following intracerebral injection of IFN-g. J Neuroimmunol 1991; 34: 121-132.

6. Wen P, Lampson MA, Lampson LA. Effects of gamma interferon on major histocompatibility complex expression and lymphocytic infiltration in the 9L gliosarcoma brain tumor model: Implications for strategies of immunotherapy. J Neuroimmunol 1992; 36: 57-68.

7. Whelan JP, Eriksson U, Lampson LA. Expression of mouse b2-microglobulin in frozen and formaldehydefixed central nervous tissues: Comparison of tissue behind the blood-brain barrier and tissue in a barrierfree region. J Immunol 1986; 137: 2561-2566.

8. Whelan JP, Wysocki CJ, Lampson LA. Distribution of b2-microglobulin in olfactory epithelium: A proliferating neuroepithelium not protected by a blood-tissue barrier. J Immunol 1986; 137: 2567-2571. 

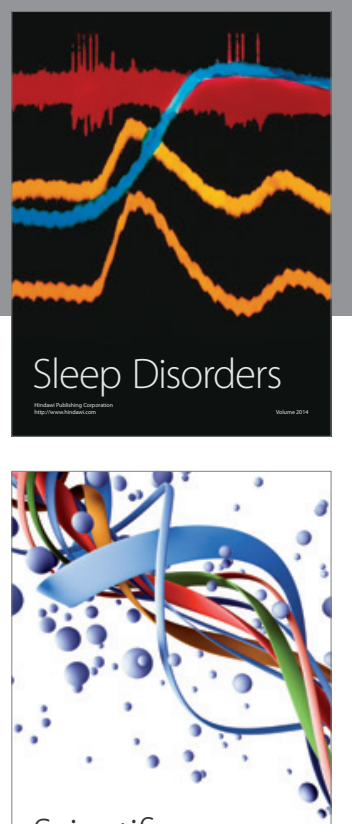

Scientifica
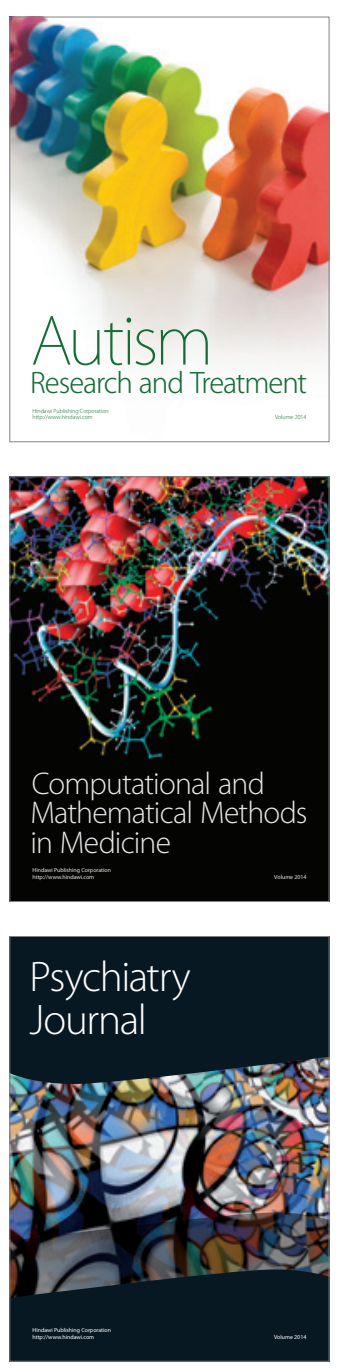
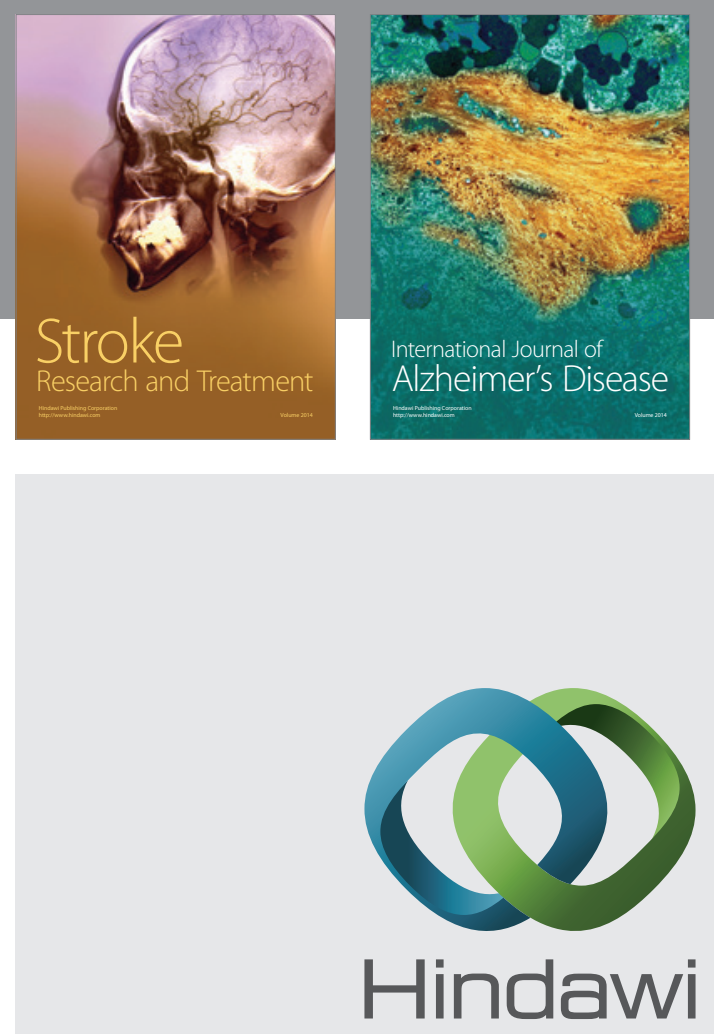

Submit your manuscripts at

http://www.hindawi.com
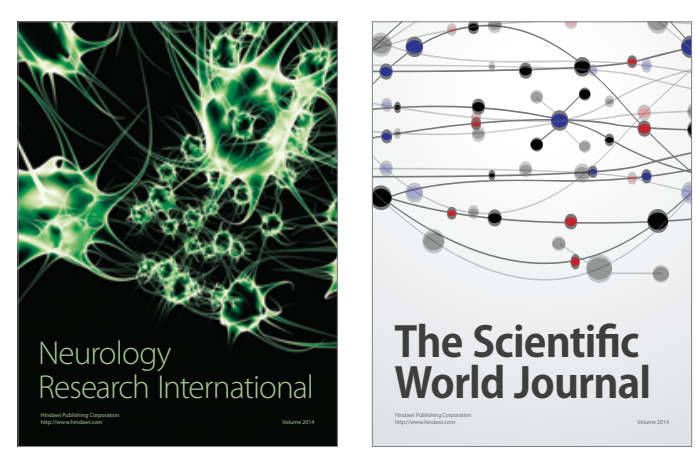

The Scientific World Journal

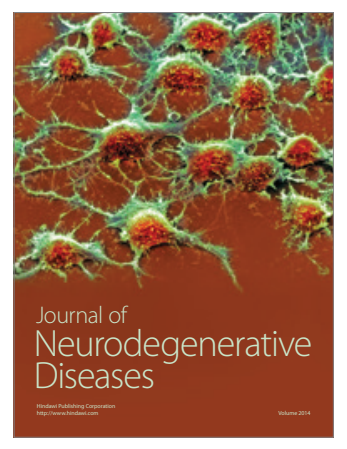

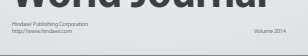

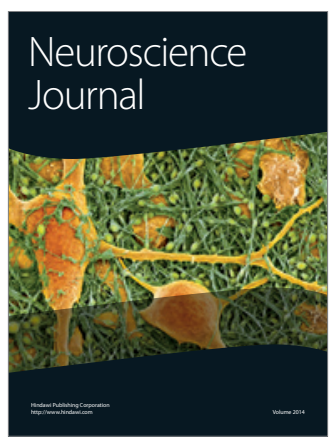

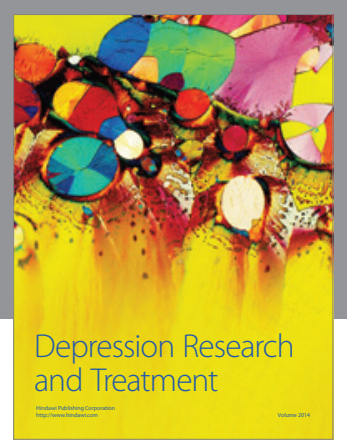
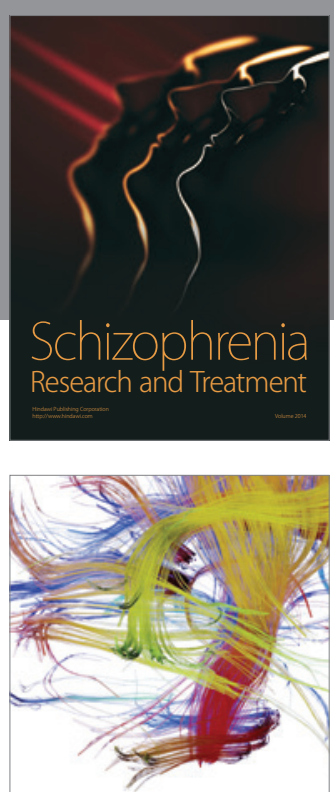

Brain Science

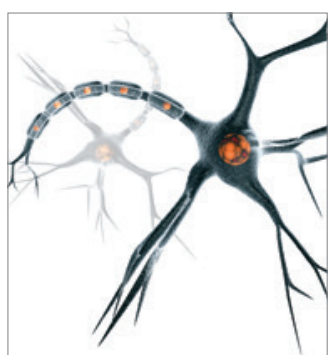

Neural Plasticity
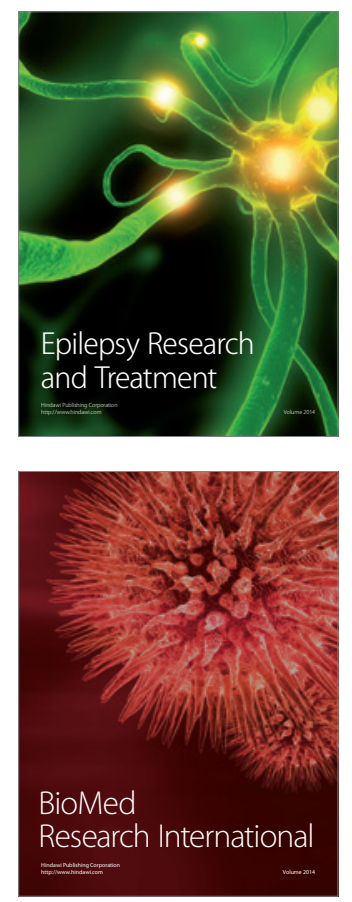

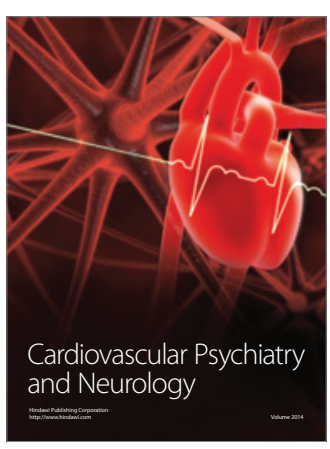

Parkinson's

Disease
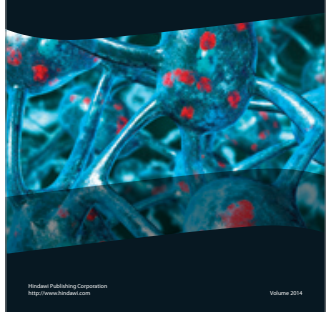